\title{
Validity Evidence of the Ethical Leadership Behavior Scale (ELBS)
}

\author{
André Luis Amorim Silva Filho' \\ Maria Cristina Ferreira ${ }^{1}$ \\ Felipe Valentini² \\ ${ }^{1}$ Universidade Salgado de Oliveira, Niterói, RJ \\ ${ }^{2}$ Universidade São Francisco, Campinas, SP
}

\begin{abstract}
The study gathered evidence of validity based on the internal structure and relations with external variables of the Ethical Leadership Behavior Scale. The study participants were 405 workers of both sexes (64.7\% female), aged 19-69 years $(M=35.7$; $S D=10.9)$, who answered the Brazilian version of the scale and instruments to assess other constructs. The confirmatory factor analyses pointed to a final version of 35 items concentrated in a single factor, with an internal consistency index of 0.96 . In the validity evidence in relation to external variables, the scale was positively and moderately correlated with work engagement, job satisfaction, and affective organizational commitment; weakly and positively with general mental health; and weakly and negatively with burnout. The future use of the scale in organizational research and diagnostics on ethical leadership behavior is recommended.

Keywords: factor analysis; statistical validity; leadership; ethics; work
\end{abstract}

Evidências de Validade da Escala de Comportamento de Liderança Ética (ECLE)

\begin{abstract}
Resumo
O estudo reuniu evidências de validade baseadas na estrutura interna e nas relações com variáveis externas da Escala de Comportamento de Liderança Ética. Participaram do estudo 405 trabalhadores, de ambos os sexos (64,7\% do sexo feminino), com idades variando entre 19 e 69 anos $(M=35,7 ; D P=10,9)$, que responderam à versão brasileira da escala e a instrumentos para avaliação de outros construtos. As análises fatoriais confirmatórias apontaram para uma versão final de 35 itens concentrados em um único fator, com índice de consistência interna de 0,96 . Nas evidências de validade por relação com variáveis externas, a escala correlacionou-se positiva e moderadamente com o engajamento laboral, a satisfação no trabalho e o comprometimento organizacional afetivo; fraca e positivamente, com a saúde mental geral; fraca e negativamente com a exaustão emocional. Recomenda-se o uso futuro da escala em pesquisas e diagnósticos organizacionais sobre o comportamento de liderança ética. Palavras-chave: análise fatorial, validade estatística, liderança, ética, trabalho
\end{abstract}

\section{Evidencias de Validez de la Escala de Comportamiento de Liderazgo Ético (ECLE)}

\begin{abstract}
Resumen
El estudio reunió evidencias de validez basadas en la estructura interna y en las relaciones con variables externas de la Escala de Comportamiento de Liderazgo Ético. Participaron del estudio 405 trabajadores, de ambos sexos (64,7\% de sexo femenino), con edades entre 19 y 69 años $(M=35,7 ; D E=10,9)$, los cuales respondieron la versión brasileña de la escala e instrumentos para la evaluación de otros constructos. Los análisis factoriales confirmatorios indicaron una versión final de 35 ítems concentrados en un único factor, con índice de consistencia interna de 0,96. En las evidencias de validez por relación con variables externas, la escala se correlacionó positiva y moderadamente con el compromiso laboral, satisfacción en el trabajo y compromiso organizacional afectivo; débil y positivamente con la salud mental general; débil y negativamente con el agotamiento emocional. Se recomienda el uso futuro de la escala en investigaciones y diagnósticos organizacionales sobre el comportamiento de liderazgo ético.

Palabras clave: análisis factorial; validez estadística; liderazgo; ética; trabajo
\end{abstract}

Corruption scandals involving high-ranking members of large corporations have come to the fore and highlight the fact that some individuals often make decisions devoid of ethical values and driven only by profit and ambition for accumulation (Fein \& Wiebler, 2014; Köbis, van Prooijen, Righetti, \& van Lange, 2016). Other examples of ethical transgressions in the work context include maltreatment behaviors (Yang, Caughlin, Gazica, Truxillo, \& Spector, 2014), bullying
(Giorgi, Ando, Arenas, Shoss, \& Leon-Perez, 2013), sexual harassment (Higa, 2016), bribery (Randsley de Moura \& Abrams, 2013) and blackmail (Randsley de Moura \& Abrams, 2013).

This scenario reveals the need for investigations into ethical behavior in organizations, especially with regard to individuals in a leadership position, as they constitute important role models for others (Brown, Trevino, \& Harrison, 2005; Tanner, Brügger, van Schie, 
\& Lebherz, 2010). The behavior of unethical leaders can become very harmful to organizations, while leadership guided by ethical principles generally adds positive values (Eisenbeiß \& Giessner, 2012).

A specific type of leadership has recently led to an increasing volume of studies, namely ethical leadership, which consists in the manifestation by leaders of personal behaviors and practices of normatively appropriate interpersonal relationships, as well as in encouraging these actions in their followers by means of communication, reinforcement and clear decision making (Brown et al., 2005). This form of leadership is thus associated with ethical awareness and adherence to high moral values in different circumstances, despite the risk of negative consequences for the leaders who practice it (Tanner et al., 2010).

According to the theory of social learning (Bandura, 1971), the individual, in vicarious learning by modeling, learns a certain behavior by observing the conduct of others, without the need for reinforcement, which is very common in the leader-led relationship. Thus, the ethical behaviors the leaders manifest present great potential to be disseminated in the lower hierarchical levels.

Despite the importance of ethical leadership for contemporary organizations, few tools exist for its evaluation, although those already developed have satisfactory psychometric characteristics and solid theoretical support (Tanner et al., 2010). Among these tools, the Perceived Leader Integrity Scale (PLIS) (Craig \& Gustafson, 1998), the Ethical Leadership Scale (ELS) (Brown et al., 2005) and the Leadership Virtues Questionnaire (LVQ) (Riggio, Zhu, Reina, \& Maroosis, 2010) stand out.

Tanner et al. (2010) observed the following limitations in ethical leadership scales though: (i) their items are sometimes abstract and do not faithfully reflect the behaviors observed in leaders; (ii) the items sometimes require knowledge about ethics to be answered, and (iii) the tools consider trust as a characteristic of ethical leadership rather than as a consequence of this type of leadership. In an attempt to overcome these limitations and develop a measure that encompasses a wide range of ethical behaviors and is able to detect individual differences among these behaviors, the authors have proposed the Ethical Leadership Behavior Scale (ELBS) (Tanner et al., 2010).

The theoretical model of ELBS is based on the perspective of Brown et al. (2005), according to which ethical leaders establish clear and exemplary ethical standards by being seen as trustworthy, fair and concerned with others. In addition, the authors also rested on contributions from the studies on authentic leadership (Gardner, Avolio, Luthans, May, \& Walumbwa, 2005; Walumbwa, Avolio, Gardner, Wernsing, \& Peterson, 2008), according to which (moral) authenticity is achieved when individuals act in accordance with their "true self," expressing themselves in accordance with their deeper personal (moral) values and convictions. Based on these conceptions, Tanner et al. (2010) elaborate a scale to evaluate the perception of ethical leadership that meets the following criteria: (a) adherence to the ethical values of justice, support, respect, and honesty; (b) ethical behavior despite difficulties; (c) consistency over time and situations.

The process of creating items for ELBS initially involved the following steps: (a) interview with workers and their supervisors; (b) generation of a wide range of items based on the literature and interviews; (c) an exploratory study with 442 students to ensure that the items unambiguously represented demonstrations of behaviors of the four values investigated (justice, support, respect, and honesty); (d) evaluation of the item fit, requesting that students with work experience shorten and simplify items to eliminate those that were redundant.

After these steps, a preliminary set of 74 items remained. To further ensure the content validity, a sample of 23 students was asked to relate each behavioral item to one of the four values that served as a basis for the construction of the scale. Only items classified in the same category by at least $70 \%$ of the participants were included in the survey. Thus, the set of items was reduced from 74 to 49 . In a later analysis with 592 workers, the instrument was reduced to 35 items, assembled in a single factor, using the Rasch model. The reliability of the instrument was 0.95 in this original study (Tanner et al., 2010).

There are no scales constructed or adapted in Brazil for the purpose of evaluating this construct though, according to a survey carried out in Brazilian databases (Scielo and Pepsic) in June 2018. Therefore, investigations are justified that can offer evidence of validity on the Ethical Leadership Behavior Scale (ELBS) in Brazilian samples. We hope that the development of this measure will contribute to the future diagnosis of individuals' ability to exercise leadership with ethical awareness, as well as the development of research aimed at deepening the nomological network of this construct, especially with regard to its 
implications for occupational well-being and organizational performance.

Based on these considerations, the general objective of this study was to adapt and gather evidence of validity based on the internal structure and relations with external variables, as well as internal consistency of ELBS in a sample of Brazilian workers. Considering the studies by Tanner et al. (2010), the hypothesis was raised that, in the Brazilian adaptation of the scale, the one-factor model would better fit the data (H1).

Regarding the evidence of validity through relations with external variables, five variables were chosen for the purpose of correlation with the perceived ethical leadership behavior, namely: job satisfaction, work engagement, affective organizational commitment, general mental health, and emotional exhaustion. Job satisfaction is characterized as a positive inner state resulting from the work performed (Eggerth, 2015). Previous studies have shown a moderate positive association between ethical leadership and job satisfaction (Tanner et al., 2010). It is to be expected, therefore, that the positive stimulus coming from the behaviors of ethical leaders inspires followers to perform their tasks properly, which will favor the feeling of job satisfaction (Brown et al., 2005). In this sense, it was hypothesized that the perception of the direct leader's ethical leadership behavior would have a moderate positive correlation with the employee's job satisfaction (H2).

Work engagement is a positive mental state towards work, manifested in feelings of vigor, dedication, and absorption (Bakker, 2014). Tanner et al. (2010) found a moderate positive correlation between ethical leadership behavior and work engagement. Therefore, the perception of ethical leadership behavior can favor greater work engagement when workers observe their leader acting ethically with them. In other words, when employees are treated with respect and justice (Tanner et al., 2010), they tend to manifest positive mental states and engage further in fulfilling their tasks and achieving their work goals (Demirtas, Hannah, Gok, Arslan, \& Capar, 2015; Mitonga-Monga, Flotman, \& Cilliers, 2016). In this sense, the hypothesis was raised of a moderate positive correlation between the perception of the direct leader's ethical leadership behavior and the work engagement of the employee (H3).

The affective organizational commitment is characterized by the identification and involvement the worker manifests in relation to the organization he works for (Kabat-Farr, Cortina, \& Marchiondo, 2018). It is possible, therefore, that workers who identify the ethical leader as a representative of the organization that supports them are led to develop greater identification and involvement with it (Demirtas, \& Akdogan, 2015). Tanner et al. (2010) found a weak positive correlation between ethical leadership behavior and affective organizational commitment. Thus, it was hypothesized that the perception of the direct leader's ethical leadership behavior would have a weak positive correlation with the affective organizational commitment of the employee (H4).

General mental health consists of the absence of non-severe psychiatric illness (Goldberg, 1972). Considering that ethical leaders often face challenges and take risks involved in different job situations, in order to protect the employees under their leadership (Tanner et al., 2010), the perception of such behavior may favor the mental health of these employees. In other words, it is possible that the perception of ethical leadership is associated with higher levels of mental health. Consistent with those arguments, Tanner et al. (2010) found a weak negative correlation between the perceived ethical leadership behavior and health claims. Based on this finding, the hypothesis was raised that the perception of the direct leader's ethical leadership behavior would have a weak positive correlation with the general mental health of the employee (H5).

Emotional exhaustion consists of a prolonged response to chronic emotional and interpersonal stressors arising from work, manifested in the depletion of emotional resources (Schaufeli, Leiter, Maslach, \& Jackson, 1996). Considering that the ethical leader is able to alleviate the high emotional demands arising from work, by assuming most of the emotional risks involved in the tasks delegated to him (Tanner et al., 2010), it can be assumed that the perception of such behavior will protect his employees against eventual emotional exhaustion. In this sense, a weak negative correlation was observed between ethical leadership behavior and emotional exhaustion (Tanner et al., 2010). Thus, the hypothesis was raised that the perception of the direct leader's ethical leadership behavior would have a weak negative correlation with the emotional exhaustion of the employee (H6).

\section{Method}

\section{Participants}

In this research, a convenience sampling process was used, consisting of 405 workers, ranging from 19 to 69 years of age $(\mathrm{M}=35.7, \mathrm{SD}=10.9)$, male and 
female $(64.7 \%)$, with distinct educational levels $(50.0 \%$ had postgraduate studies, $24.0 \%$ completed higher education, $20.7 \%$ incomplete higher education and 5.1\% technical or medium level). The participants came from different job areas $(26.7 \%$ from the educational area, $16.8 \%$ from service providers and $15.1 \%$ from the health area). Of these workers, $54.5 \%$ belonged to the private sector. Regarding the organizational level, 25.6\% of the sample had some leadership position (supervisor, manager, etc.), while $74.4 \%$ exclusively worked under someone's leadership. It should be noted, however, that $100 \%$ of the sample had at least one hierarchical superior, i.e. an immediate leader. Thus, all participants were asked to respond to the leadership questionnaire with reference to their immediate leaders, which is why, in the present research, all of them took the position of employees under leadership. Total length of experience ranged from 1 to 51 years $(M=13.9, S D=10.7)$. To be included in the sample, respondents should be 18 years of age or older, willing to participate in the study and working or being training for at least one year prior to the application of the survey.

\section{Instruments}

To evaluate the perceived ethical leadership behavior, the Ethical Leadership Behavior Scale was translated and adapted to the Brazilian context. It consists of 35 items, to be answered on five-point Likert scales, ranging from I strongly disagree (1) to I strongly agree (5). An example item is: "Admits his/her mistakes". Participants were asked to respond to what extent they believed that their immediate boss demonstrated the ethical leadership behaviors present in ELBS.

The scale adaptation process involved the following procedures: (a) initial translation into Portuguese by two independent Brazilian translators fluent in English; (b) synthesis and analysis of the translations by the authors; (c) back-translation by a bilingual translator (Portuguese-English); review by expert committee with five members, including post-graduation students with practical and academic experience in the organizational area; (e) final review by the authors (all bilingual) to verify the semantic equivalence and fit of each item in the original tool to the adapted scale (Borsa, Damásio, \& Bandeira, 2012).

Job satisfaction was evaluated by means of the General Job Satisfaction Scale, constructed and with evidence of validity obtained by Silva and Ferreira (2009). The single-factor instrument consists of five items, to be answered on five-point Likert scales, ranging from I strongly disagree (1) to I strongly agree (5). An example of an item is: "I feel satisfied with my current job". Its internal consistency coefficient, calculated by Cronbach's Alpha, was equal to 0.90 .

Affective organizational commitment at work was evaluated using the Meyer and Allen Affective Commitment Scale (1991), with evidence of validity in Brazilian samples obtained by Ferreira, Assmar, Souto, Braga, Rocha and Pacheco (2002). This also one-factor scale consists of six items, to be answered on five-point Likert scales, ranging from I strongly disagree (1) to I strongly agree (5). An example of an item is: "I feel emotionally attached to my organization". The internal consistency index of the scale was 0.90 .

Work engagement was evaluated using the short version of the Work Engagement Scale (WES-9) by Schaufeli, Bakker and Salanova (2006), adapted to the Brazilian context by Ferreira et al. (2016). It consists of nine items (for example: "In my work, I feel full of energy"), to be answered on five-point Likert scales ranging from never (1) to daily (5). The internal consistency of the scale, evaluated by Cronbach's alpha, was equal to 0.93 .

For the evaluation of mental health, the short version of the Goldberg General Health Questionnaire (1972) was used, adapted for Brazil by Gouveia, Chaves, Oliveira, Dias, Gouveia and Andrade (2003). It consists of 12 items (for example, "Have you lost your self-confidence?"), to be answered on five-point Likert scales ranging from absolutely not (1) to very frequently (5). The internal consistency of the scale was equal to 0.90 .

Emotional exhaustion was assessed by the emotional exhaustion scale of the Maslach Burnout Inventory - General Survey (MBI-GS) developed by Schaufeli et al. (1996), specifically for professionals without direct contact with clients or the general public, and validated in Brazilian samples by Silva Jr. (2005). This scale consists of a single factor and five items, to be answered on five-point Likert scales ranging from never (1) to daily (5). An example of an item is: "I feel emotionally exhausted because of my work." The internal consistency of the scale was equal to 0.91 . The data collection instrument also included a sociodemographic questionnaire and a free and informed consent form.

\section{Data collection and analysis procedures}

After approval by the Research Ethics Committee (CAAE: 54900316.6.0000.5289), the instruments were applied individually and electronically to those 
who voluntarily opted to participate. These individuals initially completed the free and informed consent form and then completed the scales in their free time. The confidentiality of the information provided to all participants was ensured.

To evaluate the dimensionality of the scale, a parallel analysis was carried out through 500 bootstrap resamples, using permutations with the real database. The parameters were estimated by means of Minimum Rank Factor Analysis, based on polychoric correlations. Confirmatory factor analyses were performed using MPlus version 6.12, using weighted least squares means and variance (WLMSV) as parameter estimation method. The adjustment indices evaluated and the adopted reference values included at least the following requirements: $\chi^{2} / \mathrm{gl}<5$; CFI $>0.95$; TLI $>0.95$; RMSEA <0.05 (Hox \& Bechger, 1998).

The internal consistency assessment was performed using Cronbach's alpha coefficient and composite reliability, and the investigation of validity evidence based on relationships with external variables of the Ethical Leadership Behavior Scale was performed by calculating Pearson's correlations between the scale scores and the correlated construct scores, as presented in the hypotheses. In the interpretation of the magnitude of the correlation coefficients, Cohen's criteria (1992) were adopted, which classify it according to the following intervals: $0.10-0.29$ (low); $0.30-0.49$ (moderate) and greater than 0.50 (high).

\section{Results}

In order to evaluate the dimensionality, the parallel analysis indicated the extraction of two dimensions (in order of factors, percentage of explained variance of the actual data: $49 \%, 7.3 \%$ and $4.9 \%$, in order of factors, percentage of explained variance of the random data: $6.3 \%, 5.9 \%$ and $5.6 \%$ ). It was noticed, however, that the dimensions separated the items from the positive and negative poles of the construct, regardless of the contents of the items. As such separate dimensions are not theoretically interpretable, they must be related to difficulty factors rather than to content factors. Therefore, we decided to maintain the one-dimensional structure originally proposed.

In order to evaluate the internal structure of the ELBS, by means of confirmatory factor analysis, using the weighted least squares means and variance (WLMSV) method for parameter estimation, the adjustment indices of a one-factor model containing the 35 items of the original scale were initially calculated, which provided the following indicators: $\chi^{2}(560)=3227.49 ; \chi^{2} /$ $\mathrm{gl}=5.76$; $\mathrm{RMSEA}=0.108$ (range 0.105-0.112), $\mathrm{CFl}=$ 0.877 ; $\mathrm{TLI}=0.880$. Considering that these indices were not satisfactory, the residuals of the item pairs 16 and 17, 20 and 17, 27 and 28,13 and 19,14 and 15, 22 and 23 and 31 and 32 were correlated. After the modification, the indices were reasonably satisfactory: $\chi^{2}$ (553) $=2399.88$ (553); $\chi^{2} / \mathrm{gl}=4.34 ; \mathrm{RMSEA}=0.091$ (range 0.087-0.095), CFI $=0.922$; TLI $=0.916$. This solution was then chosen to compose the final model, which permitted the partial confirmation of Hypothesis 1, in function of the acceptable adjustment indices, although a little lower than expected.

Assuming a 95\% confidence interval, the nonstandardized parameters of this solution were all significantly different from zero, with critical ratio values superior to 1.96 , indicating that all parameters can be considered useful to the model. Table 1 shows the standard factor loadings of the final ELBS model. The internal consistency ratio of the scale, calculated using Cronbach's Alpha, and the composite reliability (or construct reliability) were equal to 0.96 .

We also tried to evaluate the evidence of validity based on the relations with external variables of the scale. Therefore, the scores obtained in each of the data collection instruments were initially calculated, as well as the means, standard deviations, and correlations between these scales (Table 2).

The data obtained showed that the Ethical Leadership Scale correlated positive and moderately with the Job Satisfaction Scale $(r=0.43, p<0.01)$, with the Work Engagement Scale $(r=0.36, p<0.01)$ and with the Affective Organizational Commitment Scale $(r=$ $0.32, p<0.01)$, which fully confirmed Hypotheses 2 and 3 and partially confirmed Hypothesis 4. In addition, it correlated weak and positively with the General Health Questionnaire $(r=0.27, p<0.01)$ and weak and negatively with the Emotional Exhaustion Scale $(r=$ -0.29, $p<0.01$, which also permitted the full confirmation of Hypotheses 5 and 6.

\section{Discussion}

This study was aimed at investigating the initial evidence of validity of the Ethical Leadership Behavior Scale in Brazilian samples. With regard to the confirmatory factor analysis, the data obtained revealed that the most fitted model was the adjusted one-factor model. It should be taken into account, however, that the data 
Table 1.

Standardized parameters

\begin{tabular}{|c|c|c|c|c|c|c|}
\hline \multirow{2}{*}{ Parameters } & \multicolumn{6}{|c|}{ Standardized parameters } \\
\hline & $\lambda$ & $\tau 1$ & $\tau 2$ & $\tau 3$ & $\tau 4$ & $\tau 5$ \\
\hline LE1 & $-0,526$ & $-1,275$ & $-0,549$ & $-0,065$ & 1,013 & 2,811 \\
\hline LE2 & $-0,698$ & $-1,111$ & $-0,424$ & 0,090 & 1,044 & 2,811 \\
\hline LE3 & $-0,692$ & $-1,221$ & $-0,397$ & 0,285 & 1,234 & - \\
\hline LE4 & $-0,591$ & $-1,208$ & $-0,557$ & 0,109 & 1,066 & 2,811 \\
\hline LE5 & $-0,715$ & $-1,464$ & $-0,887$ & $-0,493$ & 0,765 & 2,811 \\
\hline LE6 & $-0,759$ & $-1,261$ & $-0,542$ & $-0,109$ & 0,724 & - \\
\hline LE7 & $-0,787$ & $-1,303$ & $-0,669$ & $-0,171$ & 0,748 & - \\
\hline LE8 & $-0,791$ & $-1,013$ & $-0,431$ & 0,115 & 1,044 & - \\
\hline LE9 & $-0,754$ & $-1,208$ & $-0,493$ & 0,071 & 1,013 & - \\
\hline LE10 & $-0,675$ & $-1,182$ & $-0,458$ & 0,121 & 1,077 & 2,811 \\
\hline LE11 & $-0,709$ & $-1,261$ & $-0,646$ & $-0,158$ & 0,953 & - \\
\hline LE12 & $-0,716$ & $-1,158$ & $-0,514$ & 0,121 & 1,170 & - \\
\hline LE13 & $-0,740$ & $-1,501$ & $-0,756$ & $-0,370$ & 0,740 & 2,811 \\
\hline LE14 & $-0,767$ & $-1,676$ & $-1,055$ & $-0,424$ & 0,748 & - \\
\hline LE15 & $-0,604$ & $-1,728$ & $-0,887$ & $-0,279$ & 0,676 & - \\
\hline LE16 & 0,469 & $-1,099$ & $-0,364$ & 0,337 & 1,195 & - \\
\hline LE17 & 0,609 & $-1,055$ & $-0,344$ & 0,209 & 1,099 & - \\
\hline LE18 & 0,480 & $-1,303$ & $-0,451$ & 0,311 & 1,348 & - \\
\hline LE19 & $-0,757$ & $-1,728$ & $-0,992$ & $-0,331$ & 1,023 & - \\
\hline LE20 & 0,735 & $-0,833$ & $-0,133$ & 0,716 & 1,464 & - \\
\hline LE21 & $-0,523$ & $-1,289$ & $-0,451$ & 0,285 & 1,195 & - \\
\hline LE22 & 0,677 & $-0,798$ & 0,102 & 0,850 & 1,627 & - \\
\hline LE23 & 0,654 & $-0,716$ & $-0,015$ & 0,557 & 1,412 & - \\
\hline LE24 & 0,743 & $-0,748$ & 0,222 & 0,773 & 1,604 & - \\
\hline LE25 & $-0,584$ & $-1,540$ & $-0,807$ & $-0,209$ & 1,099 & - \\
\hline LE26 & 0,725 & $-0,571$ & 0,542 & 1,195 & 1,786 & - \\
\hline LE27 & 0,787 & $-0,479$ & 0,298 & 0,887 & 1,540 & - \\
\hline LE28 & 0,759 & $-0,410$ & 0,377 & 1,034 & 1,561 & - \\
\hline LE29 & 0,719 & $-0,514$ & 0,564 & 1,158 & 1,886 & - \\
\hline LE30 & 0,763 & $-0,417$ & 0,528 & 1,170 & 1,924 & - \\
\hline LE31 & 0,787 & $-0,370$ & 0,542 & 1,182 & 1,851 & - \\
\hline LE32 & 0,808 & $-0,397$ & 0,344 & 0,842 & 1,429 & - \\
\hline LE33 & 0,696 & $-0,472$ & 0,127 & 0,807 & 1,429 & - \\
\hline LE34 & 0,791 & $-0,215$ & 0,451 & 1,088 & 1,818 & - \\
\hline LE35 & 0,718 & 0,065 & 0,700 & 1,261 & 1,818 & - \\
\hline
\end{tabular}


Table 2.

Means, standard deviations and correlation coefficients between the research scales

\begin{tabular}{lcccccccc}
\hline Variables & $\mathrm{M}$ & $\mathrm{SD}$ & 1 & 2 & 3 & 4 & 5 & 6 \\
\hline 1- Ethical leadership behavior & 3,46 & 0,78 & - & - & - & - & - & - \\
2 - Job satisfaction & 3,14 & 1,10 & $0,43^{* *}$ & - & - & - & - & - \\
3 - Work engagement & 3,55 & 0,97 & $0,36 * *$ & $0,69^{* *}$ & - & - & - & - \\
4 - Affective organizational commitment & 3,21 & 1,02 & $0,32^{* *}$ & $0,65^{* *}$ & $0,62^{* *}$ & - & - & - \\
5 - General mental health & 3,61 & 0,79 & $0,27 * *$ & $0,47 * *$ & $0,54^{* *}$ & $0,35^{* *}$ & - & - \\
6 - Emotional exhaustion & 2,94 & 1,06 & $-0,29 * *$ & $-0,49 * *$ & $-0,55^{* *}$ & $-0,40^{* *}$ & $-0,51^{* *}$ & - \\
\hline
\end{tabular}

${ }^{* *} p<0,01$

obtained did not permit an ideal fit, as recommended by the literature in the area, although the fit indicators were only slightly lower than expected (Hox \& Bechger, 1998).

It should be emphasized, also, that this is a onefactor model, containing 35 items. In these cases, the parameters to be estimated, all related to a single dimension, tend to generate a high amount of residuals. Consequently, the model tends to have adjustment indicators below the pre-established cut-off points. On the other hand, even if the estimation of additional factors could increase the adjustment indicators, such a change in the model would not be theoretically justified. Thus, for example, it is not possible to theoretically interpret factors that join only negative items, regardless of the behavioral content of these items. In addition, the pairs of items whose residues were correlated do not present a pattern capable of supporting a hypothesis of additional specific factors (beyond what the general dimension already explained). In other words, the residual correlations seem to be capturing specificities of random pairs of items whose contents are similar. The absence of a standard would not justify the modeling of additional factors or of a bifactor model though.

Thus, the final Brazilian version of the Ethical Leadership Behavior Scale continued with 35 items, maintaining its one-factor structure, similar to the original model (Tanner et al., 2010). In addition, it presented good composite reliability $(\mathrm{CR}=0.96)$ and internal consistency, calculated by Cronbach's alpha $(\alpha=0.96)$. These results converge with Tanner et al. (2010), who found an index equal to 0.95 .

Regarding validity evidence of the scale based on relations with external variables, it was observed that the perceived ethical leadership behavior correlated positively and moderately with job satisfaction $(r=$
0.43), thus confirming Hypothesis 2. This finding is consistent with Tanner et al. (2010), who also found a moderate positive correlation between the perceived ethical leadership behavior and job satisfaction $(r=$ 0.39). In this sense, the more ethical the perceived leadership behavior, especially manifested in attitudes perceived as fair, honest, respectful, and supportive of subordinates, the more likely the subordinates are to be satisfied with their work (Brown et al., 2005; Tu, Lu, \& Yu, 2017).

A moderate positive correlation $(r=0.36)$ was also observed between the perceived ethical leadership behavior and work engagement, thus confirming Hypothesis 3. This finding is consistent with Tanner et al. (2010), who also found a moderate positive correlation between the perceived ethical leadership behavior and work engagement $(r=0.34)$. In this sense, when the worker perceives that he receives support from his leader and is treated fairly and respectfully, he usually becomes more involved in his tasks and, consequently, manifests more feelings of vigor, dedication and absorption in those activities (Demirtas et al., 2015; Mitonga-Monga et al., 2016).

Regarding the perceived ethical leadership behavior and affective organizational commitment $(r=0.32)$, a moderate and positive correlation was observed between these constructs, which only partially supported Hypothesis 4. This result is nevertheless better than Tanner et al. (2010), who found a weak correlation between these constructs $(r=0.26)$. This divergence may be due to the fact that different scales were used in both studies to measure affective organizational commitment, which may have resulted in correlations of different strengths, although both scales are based on Meyer and Allen's commitment model (1991). In addition, the differences between the sample 
characteristics of both studies may also explain the divergences observed in the results. In any case, a possible interpretation of these findings is that the fact that subordinates see ethical leaders as representatives of the organizations makes them return the ethical treatment received from leaders, with feelings of greater identification and affective involvement with the organization where they work (Demirtas \& Akdogan, 2015).

The correlation between the perceived ethical leadership behavior and general mental health $(r=0.27)$ was weak and positive, and between the perceived ethical leadership behavior and emotional exhaustion it was weak and negative $(r=-0.29)$, which led to the full confirmation of Hypotheses 5 and 6. These results are in line with Tanner et al. $(r=-0.21)$, who found weak and negative correlations between perceived ethical leadership behavior and health complaints $(r=-0.21)$ and emotional exhaustion $(r=-0.19)$. One possible explanation for these findings is that ethical leaders often assume the responsibilities for major work problems or difficulties, which would ensure greater protection for the mental and emotional health of their employees. In other words, they would act as attenuators of the emotional exhaustion of their subordinates and would help to prevent possible health problems (Chughtai, Byrne, \& Flood, 2015; Mo, \& Shi, 2015; Montano, Reeske, Franke, \& Hüffmeier, 2017).

As a limitation of the study, however, it should be noted that the sample was composed of participants, mostly from the state of Rio de Janeiro, which makes it difficult to generalize the results to the other Brazilian states. Another limitation is that fitness indexes have not reached the levels recommended in the literature, which may be due to the complexity of the instrument, which has many items in a single factor.

In addition, the evidence of a one-dimensional model as the best possible (but with below-expected fitness indicators) and the presence of residual correlations may also be associated with the type of response of the scale: the self-reported Likert type format. This type of response tends to generate halo effects (Keeley, English, Irons, \& Henslee, 2013) and evaluations focused on a single aspect of the construct. In this sense, it is possible that participants rated their leaders simply as "good" or "bad" (and variations of that continuum), without regarding the specificities of that leadership (e.g. whether the leader is more democratic or more centralizing). Nevertheless, as the quantity of items is large (considering a single factor) and variation is restricted, the fitness tends not to be perfect due to apparently random residual correlations. It is suggested that future studies also test for the presence of residual correlations between the pairs of items indicated in this study, to evaluate whether or not there is a pattern in these relationships.

With regard to the accomplishment of future studies, it is suggested that investigations be accomplished to refine the scale. Considering, for example, that the scale had only one dimension, the number of items can be reduced without considerably reducing the reliability of the scores. This reduction would also tend to support a more parsimonious model with better relative fit indicators. In addition, future studies could verify the internal structure of the scale based on the self-assessment of the leadership and compare it with the data obtained through the hetero-evaluation of leadership.

Research is also recommended to deepen the nomological network of the construct, especially with regard to its impact on variables that characterize the wellbeing and quality of work life, such as flourishing at work. Such surveys could be longitudinal, which would permit a better understanding of the relationships between these variables.

The results of this study indicate, however, that the Ethical Leadership Behavior Scale presented initial evidence of validity based on the internal structure, as well as on the relationships with external variables, in a Brazilian sample. Therefore, it can be considered an appropriate measure to evaluate how ethical the behavior of the leaders can be, which recommends its future use in research and organizational diagnoses.

\section{References}

Bakker, A. B. (2014). Daily fluctuations in work engagement: An overview and current directions. European Psychologist, 19 (4), 227-236. doi:10.1027/1016-9040/ a00160

Bandura, A. (1971). Analysis of modeling processes. In A. Bandura (Ed.), Psychological modeling (pp. 1-62). Chicago: Aldine-Atherton.

Borsa, J. C., Damásio, B. F., \& Bandeira, D. R. (2012). Adaptação e validação de instrumentos psicológicos entre culturas: Algumas considerações. [Adaptation and validation of psychological instruments among cultures: Some considerations.] Paidéia (Ribeirão Preto), 22 (53), 423-432. doi: 10.1590/1982- 43272253201314

Psico-USF, Bragança Paulista, v. 24, n. 2, p. 349-359, abr./jun. 2019 
Brown, M. E., Treviño, L. K., \& Harrison, D. A. (2005). Ethical leadership: A social learning perspective for construct development and testing. Organizational Behavior and Human Decision Processes, 97(2), 117-134. doi:10.1016 /j.obhdp.2005.03.002

Chughtai, A., Byrne, M., \& Flood, B. (2015). Linking ethical leadership to employee well-being: The role of trust in supervisor. Journal of Business Ethics, 128(3), 653-663. doi:10.1007/s10551-014-2126-7

Cohen, J. (1992). A power primer. Psychological Bulletin, 112(1), 155-159. doi:10.1037/0033-2909.112.1.155

Craig, S. B., \& Gustafson, S. B. (1998). Perceived Leader Integrity Scale: An instrument for assessing employee perceptions of leader integrity. The Leadership Quarterly, 9(2), 127-145. doi:10.1016/ S1048-9843(98)90001-7

Demirtas, O., \& Akdogan, A. A. (2015). The effect of ethical leadership behavior on ethical climate, turnover intention, and affective commitment. Journal of Business Ethics, 130(1), 59-67. doi:10.1007/ s10551-014-2196-6

Demirtas, O., Hannah, S. T., Gok, K., Arslan, A., \& Capar, N. (2015). The moderated influence of ethical leadership, via meaningful work, on followers' engagement, organizational identification, and envy. Journal of Business Ethics, 145(1), 183-199. doi:10.1007/s10551-015-2907-7

Eggerth, D. E. (2015). Job satisfaction, job performance, and success. In P. Hartung, M. L. Savickas, \& W. B. Walsh (Eds.), APA handbook of career intervention (Vol. 2, pp. 453-463). Washington, DC: American Psychological Association.

Eisenbeiß, S. A., \& Giessner, S. R. (2012). The emergence and maintenance of ethical leadership in organizations: A question of embeddedness? Journal of Personnel Psychology, 11(1), 7-19. doi:10.1027/1866-5888/a000055

Fein, E., \& Wiebler, J. (2014). Review and shortcomings of literature on corruption in organizations in offering a multi-faceted and integrative understanding of the phenomenon. Behavioral Development Bulletin, 19(3), 67-77. doi: 10.1037/h0100592

Ferreira, M.C., Assmar, E. M. L., Souto, S. O., Braga, L. L., Rocha, P. M. \& Pacheco, G. L. (2002). Validação de um instrumento de comprometimento organizacional. [Validation of an instrument of organizational commitment.] Anais do I Congresso Brasileiro Psicologia Ciência e Profissão. Brasília: Conselho Federal de Psicologia.

Ferreira, M. C., Valentini, F, Damásio, B. F., Mourão, L. Porto, J. B., Chinelato, R. S. C., Novaes, V. P., \& Pereira, M. M. (2016). Evidências adicionais de validade da UWES-9 em amostras brasileiras. [Additional evidence of validity of UWES-9 in Brazilian samples.] Estudos de Psicologia (Natal), 21(4), 435-445. doi:10. 5935/1678-4669.20160042

Gardner, W. L., Avolio, B. J., Luthans, F., May, D. R., \& Walumbwa, F. O. (2005). "Can you see the real me?" A self based model of authentic leader and follower development. Leadership Quarterly, 16, 343-372. http:// dx.doi.org/10.1016/j. leaqua.2005.03.003

Giorgi, G., Ando, M., Arenas, A., Shoss, M. K., \& Leon-Perez, J. M. (2013). Exploring personal and organizational determinants of workplace bullying and its prevalence in a Japanese sample. Psychology of Violence, 3(2), 185-197. doi:10.1037/a0028049

Goldberg, D. (1972). The detection of psychiatric illness by questionnaire. London: Oxford University Press. doi:10.1017/s0033291700048613

Gouveia, V. V., Chaves, S. S. S., Oliveira, I. C. P., Dias, M. R., Gouveia, R. S. V., \& Andrade, P. R. (2003). A utilização do QSG-12 na população geral: Estudo de sua validade de construto. [The use of QSG-12 in the general population: its construct validity study] Psicologia: Teoria e Pesquisa, 19(3), 241-248. Retrieved from http://www.scielo.br/scielo.php?script $=$ sci_ arttext\& pid=S0102- 37722003000300006

Higa, F. C. (2016). Assédio sexual no trabalho e discriminação de gênero: Duas faces da mesma moeda? [Sexual harassment at work and gender discrimination: Two faces of the same coin?] Revista Direito GV, 12 (2), 484-515. doi: http://dx. doi.org/10.1590/2317-6172201620

Hox, J. J., \& Bechger, T. M. (1998). An introduction to structural equation modeling. Family Science Review, 11, 354-373. Retrieved from https://dspace. library.uu.nl/handle/1874/23738

Kabat-Farr, D., Cortina, L. M., \& Marchiondo, L. A. (2018). The emotional aftermath of incivility: Anger, guilt, and the role of organizational commitment. International Journal of Stress Management, 25(2), 109-128. doi: 10.1037/str0000045 
Keeley, J. W., English, T., Irons, J., \& Henslee, A. M. (2013). Investigating halo and ceiling effects in student evaluations of instruction. Educational and Psychological Measurement, 73, 440-457. doi: 10.1177/0013164412475300

Köbis, N. C., van Prooijen, J.-W., Righetti, F., \& Van Lange, P. A. M. (2016). Prospection in individual and interpersonal corruption dilemmas. Review of General Psychology, 20(1), 71-85. doi:10.1037/ gpr0000069

Meyer, J. P., \& Allen, N. J. (1991). A three-component conceptualization of organizational commitment. Human Resources Management Review, 1(1), 61-89. doi: 10.1016/1053-4822(91)90011-Z

Mitonga-Monga, J., Flotman, A., \& Cilliers, F. (2016). Workplace ethics culture and work engagement: The mediating effect of ethical leadership in a developing world context. Journal of Psychology in Africa, 26(4), 326-333. doi: 10.1080/14330237.2016.1208928.

Mo, S., \& Shi, J. (2015). Linking ethical leadership to employee burnout, workplace deviance and performance: Testing the mediating roles of trust in leader and surface acting. Journal of Business Ethics, 144(2), 293-303. doi: 10.1007/s10551-015-2821-z

Montano, D., Reeske, A., Franke, F., \& Hüffmeier, J. (2017). Leadership, followers' mental health and job performance in organizations: A comprehensive meta-analysis from an occupational health perspective. Journal of Organizational Behavior, 38(3), 327-350. doi: 10.1002/job.2124.

Randsley de Moura, G., \& Abrams, D. (2013). Bribery, blackmail, and the double standard for leader transgressions. Group Dynamics: Theory, Research, and Practice, 17(1), 43-52. doi:10.1037/a0031287.

Riggio, R. E., Zhu, W., Reina, C., \& Maroosis, J. A. (2010). Virtue-based measurement of ethical leadership: The Leadership Virtues Questionnaire. Consulting Psychology Journal: Practice and Research, 62(4), 235-250. doi:10.1037/ a0022286

Schaufeli, W. B., Bakker, A. B., \& Salanova, M. (2006). The measurement of work engagement with a short questionnaire: A cross-national study. Educational and Psychological Measurement, 66(4), 701-716. doi:10.1177/00131644052824 71.

Schaufeli, W. B., Leiter, M. P., Maslach, C., \& Jackson, S. E. (1996). MBI-General Survey. In M. P. Leiter, C. Maslach, \& S. E. Jackson (Eds.), Maslach Burnout Inventory manual. Palo Alto, CA: Consulting Psychologists Press.

Silva, A. P. C., \& Ferreira, M. C. (2009). Escala de Satisfação Geral no Trabalho. [Overall Satisfaction Scale at Work.]. In Instituto Brasileiro de Avaliação Psicológica (Ed.), Anais do IV Congresso Brasileiro de Avaliação Psicológica (p. 246).

Silva Júnior, D. I. (2005). A relação entre estressores ambientais e burnout em trabalhadores offshore. [The relation between environmental stressors and burnout in offshore workers.] Master's thesis, Universidade Gama Filho, Rio de Janeiro, Brazil.

Tanner, C., Brügger, A., van Schie, S., \& Lebherz, C. (2010). Actions speak louder than words: The benefits of ethical behaviors of leaders. Journal of Psychology, 218(4),225-233. doi:10.1027/0044-3409/ a000032

Tu, Y., Lu, X., \& Yu, Y. (2017). Supervisors' ethical leadership and employee job satisfaction: A social cognitive perspective. Journal of Happiness Studies, 18, (1), 229-245. doi: 10.1007/s10902-016-9725-1

Walumbwa, F. O., Avolio, B. J., Gardner, W. L., Wernsing, T. S., \& Peterson, S. J. (2008). Authentic leadership: Development and validation of a theory-based measure. Journal of Management, 34(1), 89-126. doi: 10.1177/01492063073089 13.

Yang, L.Q., Caughlin, D. E., Gazica, M. W., Truxillo, D. M., \& Spector, P. E. (2014). Workplace mistreatment climate and potential employee and organizational outcomes: A meta-analytic review from the target's perspective. Journal of Occupational Health Psychology, 19(3), 315-335. doi:10.1037/ a0036905

Received: $23 / 01 / 2018$

Reformulated: 06/29/2018; 8/13/2018

Approved: 08/29/2018 
About the authors

André Luis Amorim Silva Filho holds a PhD in Psychology from Universidade Salgado de Oliveira (UNIVERSO) and is an Organizational and Work Psychologist at the Human Resources Management Department of Universidade Federal Fluminense (UFF), Niterói - RJ. Main topics of interest: positive psychology, well-being, spirituality, positive organizational behavior and engagement.

ORCID: https://orcid.org/0000-0001-5698-9418

E-mail: aamorimsilvafilho@yahoo.com.br

Maria Cristina Ferreira holds a PhD in Psychology from Fundação Getúlio Vargas and is a full Professor and Coordinator of the Graduate Program in Psychology at Universidade Salgado de Oliveira, Niterói, RJ. Main topics of study: positive psychology, quality of life, well-being, engagement, positive organizational behavior.

ORCID: https://orcid.org/0000-0003-0752-6710

E-mail: mcris@centroin.com.br

Dr. Felipe Valentini is a professor of the Graduate School of Psychology at Universidade São Francisco, Campinas, Brazil and is an associate editor of the Brazilian Journal of Psychological Assessment. Research interests include psychometrics (mainly item response theory, structural equations, multilevel models, and response bias), psychological assessment, intelligence, and performance.

ORCID: https://orcid.org/0000-0002-0198-0958

E-mail: valentini.felipe@gmail.com

Authors' contact

Graduate Program in Psychology at UNIVERSO

Marechal Deodoro Street, 217 - Block A - 2nd Floor, Centro

Niterói-RJ, Brazil

CEP: 24030-060 